\title{
Plant species associated with different levels of species richness and of vegetation cover as indicators of desertification in Burkina Faso (West Africa)
}

\author{
Marco Schmidt ${ }^{1,2,3}$, Georg Zizka ${ }^{1,2,3}$ \\ (1) Goethe University, Institute for Ecology, Evolution and Diversity, Frankfurt am Main, Germany. \\ (2) Senckenberg Research Institute, Department of Botany and molecular Evolution, Frankfurt am Main, Germany. \\ (3) Biodiversity and Climate Research Centre $\left(\mathrm{BiK}^{\mathrm{F}}\right)$ Frankfurt am Main, Germany.
}

\begin{abstract}
Summary: Desertification is a major problem in Sudano-sahelian West Africa, including the loss of biodiversity and vegetation cover. The loss of related ecosystem services is having a severe impact on human wellbeing. To facilitate assessments of these aspects of desertification, we decided to find plant species suitable as indicators. Based on a large database of vegetation plot data for Burkina Faso, we identified species associated with high or low levels of species richness and vegetation cover by calculating average values of these measures from vegetation plots on which they occur. To account for the differences between the dry Sahel and the more humid Sudan, we separated the plots of our study area in three vegetation zones (Sahel, North Sudan, South Sudan). Furthermore, herbs and woody plants were analysed separately, as they were usually represented in different plot sizes in the primary data. For each combination of species richness or vegetation cover, vegetation zone and growth form we identified ten species indicating low and another ten species indicating high values and assigned indicator values based on the average values of these species in the relevés.
\end{abstract}

Key words: degradation, desertification, indicator species, species richness, vegetation cover

\section{ESPÈCES DE PLANTES ASSOCIÉES AVEC DIFFÉRENTS NIVEAUX DE RICHESSE SPÉCIFIQUE ET DE COUVER- TURE VÉGÉTALE COMME INDICATRICES DE DÉSERTIFICATION AU BURKINA FASO (AFRIQUE DE L'OUEST)}

Résumé: La désertification est un problème majeur dans la région soudano-sahélienne en Afrique de l'Ouest, y compris la perte de la biodiversité et de la couverture végétale. La perte des services écosystémiques a de graves répercussions sur le bien-être humain. Pour faciliter l'évaluation de ces aspects de la désertification, nous avons décidé de proposer des espèces végétales comme indicatrices des différents états de dégradation. A partir d'une grande base de données de la végétation pour le Burkina Faso, nous avons identifié des espèces liées aux niveaux élevés ou faibles de la richesse spécifique et la couverture végétale par le calcul des valeurs moyennes des parcelles de végétation dans lesquelles elles se trouvent. Pour tenir compte des différences entre le Sahel plus sec et le soudanien plus humide, nous avons séparé les parcelles de notre zone d'étude en trois zones de végétation (sahelienne, nord-soudanienne, sud-soudanienne). En outre, les herbacées et les ligneux ont été analysés séparément, car généralement étudiés dans des parcelles de différentes tailles dans les données primaires. For each combination of species richness or vegetation cover, vegetation zone and growth form we identified ten species indicating low and another ten species indicating high values and assigned indicator values based on the average values. Pour chaque combinaison de richesse spécifique ou couverture végétale, zone de vegetation et forme de croissance on a identifié dix espèces indicatrices de valeurs basses et dix espèces indicatrices de valeurs hautes basées sur les valeurs moyens de ces espèces dans les relevés.

Mots clés: dégradation, désertification, espèces indicatrices, richesse spécifique, couverture végétale

\section{Mit Verschiedenen Stufen des ARtenreichtums und der Vegetationsbedeckung assozilerte

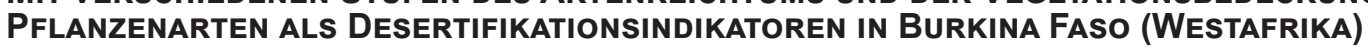

Zusammenfassung: Im sudano-sahelischen Westafrika stellt Desertifikation einschließlich des damit verbundenen Biodiversitätsverlustes und der Bodenerosion ein großes Problem dar. Der daraus resultierende Verlust an Ökosystemdienstleistungen hat schwere negative Folgen für die ansässige Bevölkerung. Um die Bewertung dieser Aspekte der Desertifikation zu erleichtern, haben wir nach als Indikatoren geeigneten Pflanzenarten gesucht. Auf der Basis einer umfassenden Datenbank von Vegetationsaufnahmen aus Burkina Faso identifizierten wir Arten, deren Vorkommen mit hoher oder geringer Ausprägung von Artenreichtum oder Vegetationsbedeckung assoziiert ist. Die Identifizierung geschah für jede einzelne Art durch Berechnung der entsprechenden Mittelwerte aus sämtlichen Aufnahmen, in denen die Art vertreten war. Um die Unterschiede zwischen den klimatisch-pflanzengeographischen Regionen des Landes zu berücksichtigen, erfolgte eine separate Berechnung für die drei Vegetationszonen Sahel, Nordsudan und Südsudan. Da krautige Arten und Gehölze in den zur Verfügung stehenden Vegetationsaufnahmen in der Regel auf unterschiedlich großen Flächen dokumentiert wurden, behandelten wir auch diese Gruppen separat. Für jede sich auf diese Weise ergebende Kategorie ermittelten wir die jeweils zehn am stärksten mit geringem bzw. hohem Artenreichtum oder geringer bzw. hoher Vegetationsbedeckung assoziierten Arten.

Schlagworte: Degradation, Desertifikation, Indikatorarten, Artenreichtum, Vegetationsbedeckung

\section{INTRODUCTION}

Desertification is defined as land degradation in drylands and is a major ecological and economical problem at global level. The United Nations Convention to Combat Desertification (UNCCD 1994) specifically mentions the loss of biological 
productivity and long-term loss of natural vegetation, which have direct effects on various ecosystem services ranging from regulating services such as soil protection and water retention to provisioning services such as fodder, food and traditional medicine. The Sudano-Sahelian savanna belt at the southern edge of the Sahara desert is one of the areas especially vulnerable to desertification (NIASSE et al. 2004) and Burkina Faso, situated directly in the centre of this region and very typical for the region with its natural vegetation and land use is a perfect study area for a case study identifying indicator species for key aspects of desertification. Based on a large database of vegetation data for West Africa (JANSSEN et al. 2011, SCHMIDT et al. 2012, http://westafricanvegetation.senckenberg.de) we identified plant species associated with high and low levels of vegetation cover and species richness. These two factors representing biological aspects of the definition of desertification proved to be effective in its documentation (GonZaLEz 2001, GonZaLez et al. 2012) and may be further connected with desertification not only as an effect, but also as a causing factor (CHARNEY et al. 1977).

\section{Methods}

For the identification of indicator species, we used phytosociological data from the West African Vegetation Database including digitized data from Ataholo (2001), BöHm (1998), Denschlag (1998), Guinko (1984), KérÉ (1996), KirchmaIr (2008), KirchmaIR et al. 2012, KroHMER (2004), KÜPPERS (1996), SCHMIDT (2006) and ZwARG (2008), which in part have been published in Ataholo \& WitTig (2011), BöHM (2001), Müller (2004), MüLler \& WitTig (2002, 2004), WitTig et al. (2003, 2011), ZwARG et al. (2012). Synonymies have been resolved following THIOMBIANO et al. (2012). As relevés have usually been done separately and on different plot sizes for herbs and woody species, we divided the pool of relevé records accordingly. Only plots of similar size (usually $100 \mathrm{~m}^{2}$ for herb plots and 900 or $1000 \mathrm{~m}^{2}$ for woody plants) have been considered, as species richness is known to increase with plot size. Using precipitation data from WorldClim (HiJmAns et al. 2005), we further separated relevés from the Sahel, the North and South Sudanian Zone. Only relevés from narrow, well-sampled rainfall ranges of $300-450 \mathrm{~mm}$ (Sahel, 771 relevés), 750 - $900 \mathrm{~mm}$ (N-Sudan, 788 relevés) and $1100-1250 \mathrm{~mm}$ (S-Sudan, 654 relevés) have been used. For each relevé, the number of occurring species has been counted and the sum of the species coverages (in percent) has been calculated. Conversion from Braun-Blanquet classes into percent has been done according to HAEUPLER (1982), the sum of coverages may exceed $100 \%$ due to overlaps and conversion. We have excluded species with less than 5 spatially unique occurrence points and calculated for all remaining species the average species richness and the average total vegetation cover of the relevés in which it occurs. These values have been used as indicator values for the species.

\section{Results}

For all combinations of measure (species richness / vegetation cover), growth form (herbaceous or woody) and vege- tation zone (Sahel, N-Sudan, S-Sudan), the 10 highest and lowest ranking species with their respective indicator values are shown in Tables 1-4.

Minimum and maximum values of species richness associated with the indicator species (Tables 1-2) are increasing with the rainfall gradient from the Sahel to the South Sudan, both for herbaceous and woody species. This is not the case for vegetation cover (Tables 3-4), where the Sudan in general has species associated with higher covers than the Sahel, but with a maximum in the North Sudan.

Only few species are indicators in more than one category, e.g. Echinochloa stagnina indicating high vegetation cover and low species richness in the Sahel. An exception is in the Sahelian woody plants (Tables 2,4 ) where several species are indicating high (or low) values of both, vegetation cover and species richness.

\section{Discussion}

Species richness (4.1) and vegetation cover (4.2) are key measures to characterize the vegetation-specific aspects of desertification and the resulting impoverishment in ecosystem services in drylands. It is however important to keep in mind that different habitat types may have naturally lower levels of plant diversity and cover, independent from detrimental impacts of human activities or climate change. It is also important to consider, that these aspects are independent from each other and species associated with low species richness may well be associated with high vegetation cover (e.g. Echinochloa stagnina).

\subsection{Species richness}

Among the high diversity indicators in the Sahel we find species like the perennial grass Andropogon gayanus which has once covered large areas of the region, now almost disappeared with increasing grazing pressure (BREMAN \& CisSÉ 1977, RIETKERK et al. 1996), but also tree species typical of intact tiger bush areas such as the Grewia spp. (Müller 2013) and trees highly valued for fodder, like Pterocarpus lucens. Within the low diversity indicators are species often occurring in nearly monospecific patches such as the Echinochloa spp. of riparian floodplains, but also two of the most frequent trees of the Sahel, Acacia tortilis and Balanites aegyptiaca which are among the few tree species remaining in the most highly degraded areas and have been identified by Wezel \& LYKKe (2006) to be increasing in the course of the Sahelian vegetation changes of the last decades.

A number of tall savanna grasses like Hyparrhenia smithiana and Andropogon tectorum are among the high diversity indicators for the North Sudan, also species typical for termite mounds such as Combretum aculeatum and Grewia bicolor (ERPENBACH et al. 2013), which may be explained by increased habitat diversity. Among the low diversity indicators, a number of species occurring on bowé (ZwARG et al. 2012), e.g. Loudetiopsis kerstingii, can be found, but also water-bound species such as Oryza longistaminata or Sarcocephalus latifolius. 
In the South Sudan, among the high diversity indicators we find species of savanna (e.g. Psorospermum febrifugum, Ziziphus abyssinica) and gallery forest (e.g. Ficus sur; THIOMBIANO et al. 2012). Some trees of the low diversity indicators are from gravelly or shallow soils.

\subsection{Vegetation cover}

Herbs indicating high vegetation cover in the Sahel include interestingly a number of $\mathrm{C} 4$ dicots (Portulaca oleracea, Boerhavia repens, Trianthema portulacastrum), but also Echinochloa stagnina, often forming dense lawns of low diversity in temporarily inundated sites. Among the trees are several species of the tiger bush (which has been shown to be a highly diverse habitat of the Sahel region by SCHMIDT et al. 2008) but also species of denser riparian forest. Low vegetation cover indicators are often species of dunes like Leptadenia pyrotechnica or of degraded glacis.

Among the North Sudanian species indicating high vegetation cover are species of high grass savanna like $H y$ parrhenia smithiana and Andropogon tectorum, open forests and termitaria thickets (e.g. Combretum aculeatum). Herbs indicating low vegetation cover are often from shallow soil areas (Polycarpaea corymbosa, Ctenium elegans). Interestingly, the indicator values for the North Sudanian

Table 1: Herbaceous species as indicators of species richness (average species richness of all relevés with the respective species is provided in brackets) / Espèces herbacées comme indicatrices de la richesse spécifique (richesse spécifique moyenne de tous les relevés contenant les espèces correspondantes est fournie entre parenthèses).

\begin{tabular}{|c|c|c|c|}
\hline & Sahel & N-Sudan & S-Sudan \\
\hline 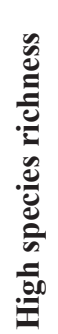 & $\begin{array}{l}\text { Eragrostis cilianensis }(16.57) \\
\text { Andropogon gayanus }(16.17) \\
\text { Cassia nigricans }(16) \\
\text { Cassia mimosoides }(15.93) \\
\text { Indigofera pilosa }(15.67) \\
\text { Evolvulus alsinoides }(15.53) \\
\text { Achyranthes aspera }(15.4) \\
\text { Pupalia lappacea }(15.38) \\
\text { Hibiscus cannabinus }(15.25) \\
\text { Ipomoea vagans }(15.11)\end{array}$ & $\begin{array}{l}\text { Indigofera kerstingii }(46.8) \\
\text { Cissus flavicans }(42.4) \\
\text { Andropogon tectorum }(42) \\
\text { Hyparrhenia smithiana }(41.6) \\
\text { Cissus adenocaulis }(40.67) \\
\text { Cienfuegosia heteroclada }(39) \\
\text { Cissus populnea }(38.4) \\
\text { Schizachyrium sanguineum }(37.71) \\
\text { Indigofera paniculata }(36.8) \\
\text { Kyllinga pumila }(36.67)\end{array}$ & $\begin{array}{l}\text { Cucumis melo }(47.56) \\
\text { Haumaniastrum buettneri }(46.63) \\
\text { Spermacoce chaetocephala }(44.86) \\
\text { Schizachyrium nodulosum }(44.43) \\
\text { Ludwigia erecta }(43.58) \\
\text { Dissotis irvingiana }(43.2) \\
\text { Phyllanthus amarus }(43) \\
\text { Vernonia cinerea }(42.82) \\
\text { Sida alba }(42.78) \\
\text { Vernonia perottetii }(42.25)\end{array}$ \\
\hline 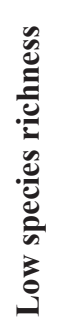 & $\begin{array}{l}\text { Setaria pumila }(10.36) \\
\text { Pancratium trianthum }(10.21) \\
\text { Cleome gynandra }(10) \\
\text { Cyperus iria }(9.45) \\
\text { Microchloa indica }(9.17) \\
\text { Trianthema portulacastrum }(9) \\
\text { Aeschynomene indica }(8.5) \\
\text { Echinochloa colona }(8.42) \\
\text { Scilla sudanica }(7.5) \\
\text { Echinochloa stagnina }(4.14)\end{array}$ & $\begin{array}{l}\text { Eriospermum flagelliforme }(13.83) \\
\text { Cyanotis longifolia }(13.74) \\
\text { Tripogon minimus }(13.62) \\
\text { Abildgaardia abortiva }(13.07) \\
\text { Loudetia simplex }(13) \\
\text { Setaria barbata }(12.75) \\
\text { Chrysopogon nigritanus }(12.6) \\
\text { Ctenium elegans }(12.5) \\
\text { Loudetiopsis kerstingii }(10.19) \\
\text { Oryza longistaminata }(7.67)\end{array}$ & $\begin{array}{l}\text { Aspilia angustifolia }(20) \\
\text { Fimbristylis dichotoma }(19.86) \\
\text { Neurotheca loeselioides }(19.5) \\
\text { Digitaria ciliaris }(19.36) \\
\text { Indigofera polysphaera }(19.17) \\
\text { Urelytrum muricatum }(19.13) \\
\text { Leersia hexandra }(18.5) \\
\text { Melochia corchorifolia }(17.6) \\
\text { Panicum subalbidum }(17.33) \\
\text { Spermacoce pusilla }(17)\end{array}$ \\
\hline
\end{tabular}

Table 2: Woody species as indicators of species richness (average species richness of all relevés with the respective species is provided in brackets) / Espèces ligneuses comme indicatrices de la richesse spécifique (richesse spécifique moyenne de tous les relevés contenant les espèces correspondantes est fournie entre parenthèses).

\begin{tabular}{|c|c|c|c|}
\hline & Sahel & N-Sudan & S-Sudan \\
\hline 龸 & $\begin{array}{l}\text { Dichrostachys cinerea }(11) \\
\text { Cadaba glandulosa }(10.83) \\
\text { Grewia flavescens }(10.46) \\
\text { Grewia bicolor }(9.96) \\
\text { Acacia ataxacantha }(9.63) \\
\text { Boscia angustifolia }(9.31) \\
\text { Acacia erythrocalyx }(9.21) \\
\text { Dalbergia melanoxylon }(8.43) \\
\text { Adansonia digitata }(8.38) \\
\text { Pterocarpus lucens }(8.34)\end{array}$ & $\begin{array}{l}\text { Excoecaria grahamii }(30.8) \\
\text { Fadogia agrestis }(30.75) \\
\text { Maerua angolensis }(30.25) \\
\text { Grewia cissoides }(26.84) \\
\text { Grewia bicolor }(26.04) \\
\text { Philenoptera laxiflora }(25.88) \\
\text { Combretum aculeatum }(25.22) \\
\text { Hymenocardia acida }(22.89) \\
\text { Vitex madiensis }(22.09) \\
\text { Pericopsis laxiflora }(21.56)\end{array}$ & $\begin{array}{l}\text { Asparagus africanus }(39.33) \\
\text { Ekebergia senegalensis }(38.67) \\
\text { Agelanthus dodoneifolius }(38.33) \\
\text { Margaritaria discoidea }(33.33) \\
\text { Smilax anceps }(33.14) \\
\text { Lannea velutina }(31.6) \\
\text { Psorospermum febrifugum (31.53) } \\
\text { Ziziphus abyssinica }(31) \\
\text { Rourea coccinea }(30.67) \\
\text { Ficus sur }(30.63)\end{array}$ \\
\hline 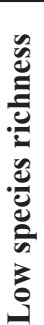 & $\begin{array}{l}\text { Acacia seyal }(5.25) \\
\text { Euphorbia balsamifera }(5.17) \\
\text { Balanites aegyptiaca }(4.98) \\
\text { Diospyros mespiliformis }(4.92) \\
\text { Acacia tortilis }(4.86) \\
\text { Faidherbia albida }(4.47) \\
\text { Acacia nilotica }(4.03) \\
\text { Acacia ehrenbergiana }(3.83) \\
\text { Leptadenia pyrotechnica }(3.37) \\
\text { Mitragyna inermis }(3.09)\end{array}$ & $\begin{array}{l}\text { Prosopis africana }(12.42) \\
\text { Parkia biglobosa }(12.11) \\
\text { Ficus platyphylla }(11.67) \\
\text { Ziziphus mauritiana }(11.65) \\
\text { Combretum paniculatum }(11.2) \\
\text { Combretum adenogonium }(10.52) \\
\text { Parinari curatellifolia }(10.1) \\
\text { Acacia seyal }(10.04) \\
\text { Sarcocephalus latifolius }(8.17) \\
\text { Terminalia macroptera }(6.6)\end{array}$ & $\begin{array}{l}\text { Burkea africana }(22.32) \\
\text { Terminalia mollis }(21.78) \\
\text { Zanha golungensis }(21.67) \\
\text { Combretum adenogonium }(21.5) \\
\text { Crossopteryx febrifuga }(21.34) \\
\text { Swartzia madagascariensis }(21) \\
\text { Manilkara obovata }(20.83) \\
\text { Maranthes polyandra }(20.82) \\
\text { Ximenia americana }(20.71) \\
\text { Ochna rhizomatosa }(19.33)\end{array}$ \\
\hline
\end{tabular}


Table 3: Herbaceous species as indicators of vegetation cover [average vegetation cover (sum of single species' covers in \%) of all relevés with the respective species is provided in brackets] / Espèces herbacées comme indicatrices de la couverture végétale [couverture végétale moyenne (somme de la couverture individuelle de toutes les espèces) de tous les relevés contenant les espèces correspondantes est fournie entre parenthèses].

\begin{tabular}{|c|c|c|c|}
\hline & Sahel & N-Sudan & S-Sudan \\
\hline 焉 & $\begin{array}{l}\text { Trianthema portulacastrum }(121.86) \\
\text { Boerhavia repens }(120.73) \\
\text { Portulaca oleracea }(119.12) \\
\text { Sida cordifolia }(117.78) \\
\text { Cleome gynandra }(110.87) \\
\text { Setaria pumila }(106.45) \\
\text { Digitaria horizontalis }(105.8) \\
\text { Ipomoea dichroa }(105.56) \\
\text { Echinochloa stagnina }(105.13) \\
\text { Sesamum alatum }(103.74)\end{array}$ & $\begin{array}{l}\text { Hyparrhenia smithiana }(147.9) \\
\text { Cissus adenocaulis }(146.75) \\
\text { Cissus populnea }(142.2) \\
\text { Cienfuegosia heteroclada }(133.25) \\
\text { Schizachyrium sanguineum }(132.34) \\
\text { Indigofera kerstingii }(130.67) \\
\text { Andropogon tectorum }(130.6) \\
\text { Cissus flavicans }(127.95) \\
\text { Indigofera stenophylla }(125.89) \\
\text { Stylosanthes fruticosa }(121)\end{array}$ & $\begin{array}{l}\text { Schizachyrium platyphyllum }(116.88) \\
\text { Melanthera elliptica }(108.89) \\
\text { Aneilema paludosum }(104.22) \\
\text { Setaria sphacelata }(104.01) \\
\text { Fimbristylis ferruginea }(102.94) \\
\text { Rhynchospora eximia }(101.4) \\
\text { Tragia senegalensis }(100.83) \\
\text { Aspilia angustifolia }(100.58) \\
\text { Aspilia paludosa }(99.87) \\
\text { Fimbristylis dichotoma }(98.88)\end{array}$ \\
\hline 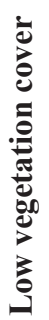 & $\begin{array}{l}\text { Polycarpaea linearifolia }(45.33) \\
\text { Boerhavia coccinea }(42.25) \\
\text { Cucumis melo }(36.94) \\
\text { Andropogon fastigiatus }(35.66) \\
\text { Tragus racemosus }(30.06) \\
\text { Mollugo nudicaulis }(28.66) \\
\text { Schizachyrium exile }(26.33) \\
\text { Cleome scaposa }(24.82) \\
\text { Euphorbia forskalii }(20.83) \\
\text { Scilla sudanica }(5.08)\end{array}$ & $\begin{array}{l}\text { Cleome viscosa }(60) \\
\text { Justicia insularis }(58.75) \\
\text { Triumfetta rhomboidea }(58.22) \\
\text { Cyanotis longifolia }(56.28) \\
\text { Blepharis maderaspatensis }(56.23) \\
\text { Sporobolus festivus }(55.42) \\
\text { Polycarpaea corymbosa }(55.03) \\
\text { Pupalia lappacea }(55.03) \\
\text { Ctenium elegans }(50.53) \\
\text { Aspilia bussei }(45.17)\end{array}$ & $\begin{array}{l}\text { Tacca leontopetaloides }(47.24) \\
\text { Pandiaka involucrata }(47.17) \\
\text { Crassocephalum togoense }(46.74) \\
\text { Loudetiopsis kerstingii }(46.45) \\
\text { Crotalaria retusa }(45.3) \\
\text { Elionurus elegans }(44.42) \\
\text { Ctenium villosum }(44.39) \\
\text { Justicia insularis }(42.72) \\
\text { Aeollanthus pubescens }(37.86) \\
\text { Tragia vogelii }(37.54)\end{array}$ \\
\hline
\end{tabular}

Table 4: Woody species as indicators of vegetation cover [average vegetation cover (sum of single species' covers in \%) of all relevés with the respective species is provided in brackets] / Espèces ligneuses comme indicatrices de la couverture végétale [couverture végétale moyenne (somme de la couverture individuelle de toutes les espèces) de tous les relevés contenant les espèces correspondantes est fournie entre parenthèses].

\begin{tabular}{|c|c|c|c|}
\hline & Sahel & N-Sudan & S-Sudan \\
\hline 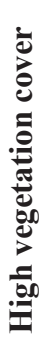 & $\begin{array}{l}\text { Dichrostachys cinerea }(72.04) \\
\text { Acacia ataxacantha }(70.35) \\
\text { Grewia bicolor }(65.28) \\
\text { Grewia flavescens }(64.44) \\
\text { Diospyros mespiliformis }(60.86) \\
\text { Feretia apodanthera }(58.59) \\
\text { Combretum micranthum }(57.56) \\
\text { Acacia erythrocalyx }(54.5) \\
\text { Boscia angustifolia }(54.07) \\
\text { Cadaba glandulosa }(52.63)\end{array}$ & $\begin{array}{l}\text { Dioscorea dumetorum }(134.6) \\
\text { Dombeya buettneri }(124.2) \\
\text { Combretum aculeatum }(114.16) \\
\text { Hymenocardia acida }(107.34) \\
\text { Bombax costatum }(94.2) \\
\text { Grewia mollis }(88.15) \\
\text { Flueggea virosa }(83.02) \\
\text { Ziziphus mucronata }(82) \\
\text { Terminalia laxiflora }(80.58) \\
\text { Grewia lasiodiscus }(80.5)\end{array}$ & $\begin{array}{l}\text { Paullinia pinnata }(79.59) \\
\text { Ekebergia senegalensis }(76.35) \\
\text { Gardenia ternifolia }(75.01) \\
\text { Ochna rhizomatosa }(75) \\
\text { Margaritaria discoidea }(70.07) \\
\text { Ochna schweinfurthiana }(69.15) \\
\text { Ficus glumosa }(68.86) \\
\text { Lannea velutina }(66.7) \\
\text { Diospyros mespiliformis }(63.59) \\
\text { Grewia mollis }(63.42)\end{array}$ \\
\hline 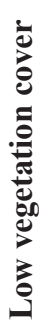 & $\begin{array}{l}\text { Grewia villosa }(31.9) \\
\text { Acacia seyal }(31.69) \\
\text { Combretum glutinosum }(30.05) \\
\text { Balanites aegyptiaca }(28.06) \\
\text { Acacia senegal }(27.94) \\
\text { Acacia tortilis }(27.17) \\
\text { Cadaba farinosa }(24.93) \\
\text { Euphorbia balsamifera }(19.44) \\
\text { Faidherbia albida }(16.41) \\
\text { Leptadenia pyrotechnica }(13.93)\end{array}$ & $\begin{array}{l}\text { Acacia seyal }(51.12) \\
\text { Xeroderris stuhlmannii }(50.46) \\
\text { Detarium microcarpum }(49.77) \\
\text { Ficus glumosa }(49.28) \\
\text { Parinari curatellifolia }(49.15) \\
\text { Commiphora africana }(49.01) \\
\text { Ziziphus mauritiana }(45.37) \\
\text { Sarcocephalus latifolius }(33.37) \\
\text { Albizia chevalieri }(30.7) \\
\text { Terminalia macroptera }(12.27)\end{array}$ & $\begin{array}{l}\text { Gardenia erubescens }(43.99) \\
\text { Terminalia schimperiana }(43.59) \\
\text { Bridelia scleroneura }(43.26) \\
\text { Pseudocedrela kotschyi }(42.11) \\
\text { Combretum adenogonium }(40.76) \\
\text { Gardenia aqualla }(40.32) \\
\text { Terminalia laxiflora }(38.49) \\
\text { Piliostigma thonningii }(38.06) \\
\text { Ximenia americana }(36.15) \\
\text { Cryptolepis oblongifolia }(32.76)\end{array}$ \\
\hline
\end{tabular}

species are higher than for the South Sudanian ones. This may be an effect of large nature reserves of the WAP complex being located in this zone and having large stands of close-to-natural habitats.

The South Sudanian high vegetation cover indicators include gallery forest species like Paullinia pinnata, low vegetation cover indicators include species of bowé and other shallow soil sites (Loudetiopsis kerstingii, Ctenium villosum).
Vegetation plot data as used in this study has proven to be a good data source to identify species associated with different levels of vegetation cover or species richness. There are however potential problems with observational data in general that might affect the results: Mere observations without any further documentation of the species are difficult to verify. In this context the practice of depositing voucher specimens in scientific collections (in this case the Herbarium Senckenbergianum) proved very useful and enabled the authors to verify the identity of species. 
The indicator species may be used by botanists and non-specialists alike. Indicator values could e.g. be used for spatial studies with distribution data from collection databases or georeferenced photo collections. For field studies, species identification is crucial but this has been facilitated for Burkina Faso in the last decade by new and updated print or online field guides (e.g. Arbonnier 2009, SaCANDÉ et al. 2012, DRESSLER et al. 2014).

\section{ACKNOWLEDGEMENTS}

We thank all contributors to our database and acknowledge funding by the European Commission for the UNDESERT project (243906) and the Hessian Initiative for the development of scientific and economic excellence (LOEWE) for the Biodiversity and Climate Research Centre (BiK-F).

\section{REFERENCES}

ArbonNiER M (2009): Arbres, arbustes et lianes des zones sèches d'Afrique de l'Ouest. 3ème ed. - Paris: MNHN \& Versailles: Editions Quae.

Ataholo M (2001): Pflanzensoziologische Untersuchungen der Segetalarten in der Sudanzone Westafrikas. - PhD thesis, Goethe-University Frankfurt.

Ataholo, M \& Wittig R (2011): The vegetation of recently fallowed Masakwa fields in the Chad basin. - Flora Veg Sudano-Sambesica 14: 24-28.

Böнм M (1998): Dorfvegetation in Burkina Faso. - Diploma thesis, J.W. Goethe-Universität Frankfurt, unpublished.

Böнм M (2001): Dorfvegetation im Sahel und Subsahel Burkina Fasos. - Ber Sonderforschungsbereich 268 17: 193 225.

Breman H, Cissé AM (1977): Dynamics of Sahelian pastures in relation to drought and grazing. Oecol 28: 301-315.

Charney JM, Quirk WJ, Chow SH \& Kornfield J (1977): A comparative study of the effects of albedo change on drought in semi-arid regions. J Atmosphere Sci 34:13661386.

Denschlag J (1998): Ethnobotanische und pflanzensoziologische Untersuchungen der Gehölzvegetation bei den Fulbe im Südosten von Burkina Faso (Westafrika). - Diploma thesis, Goethe-University Frankfurt, unpublished.

Dressler S, Schmidt M \& ZizKa G (2014): African Plants - a photo guide. URL: http://www.africanplants.senckenberg.de.

ERPENBaCh A, Bernhardt-RöMERmann M, Wittig R, ThIOMBIANO A \& HAHN K (2013): The influence of termite-induced heterogeneity on savanna vegetation along a climatic gradient in West Africa. J Trop Ecol 29: 11-23.

GonZALEZ P (2001): Desertification and a shift of forest species in the West African Sahel. Clim Res 17: 217-228.

GonZalez P, Tucker CJ \& Sy H (2012): Tree density and species decline in the African Sahel attributable to climate. J Arid Environment 78: 55-64.

Guinko S (1984): Végétation de la Haute Volta. - Dissertation, Université de Bordeaux III.

Haeupler H (1982): Evenness als Ausdruck der Vielfalt in der Vegetation. - Vaduz: J. Cramer.

Hijmans RJ, Cameron SE, Parra JL, Jones PG \& Jarvis A (2005): Very high resolution interpolated climate surfaces for global land areas. Internat J Climatol 25: 1965-1978.
Janssen T, Schmidt M, Dressler S, Hahn-Hadjali K, Hien M, Konaté S, Lykke AM, Mahamane A, Sambou B, Sinsin B, Thiombiano A, Wittig R \& Zizka G (2011) Addressing data property rights concerns and providing incentives for collaborative data pooling: the West African Vegetation Database approach. J Veg Sci 22: 614-620.

KÉRÉ U (1996): Die Dorf- und Savannenvegetation in der Region Tenkodogo (Burkina Faso). - PhD thesis, GoetheUniversity Frankfurt.

KÉRÉ U (1998): Vegetation und Wildpflanzennutzung in der Region Tenkodogo (Burkina Faso) / Végétation et utilisation des plantes spontanées dans la région de Tenkodogo (Burkina Faso). - Étude flore vég Burkina Faso 4: 3-55.

KIRChMAIR I (2009): Flora und Vegetation auf Termitenhügeln in Nordbenin. - Diploma thesis, Goethe University Frankfurt, unpublished.

Kirchmair I, Schmidt M, Hahn K, ERPenbach A, ZizKa G (2012): Biodiversity Islands in the Savanna - Analysis of the Phytodiversity on Termite Mounds in Northern Benin. Flora et Vegetatio Sudano-Sambesica 15: 3-14.

KROHMER J (2004): Umweltwahrnehmung und -klassifikation bei Fulbegruppen in verschiedenen Naturräumen Burkina Fasos und Benins. - PhD thesis, Goethe University Frankfurt.

KüPPERS K (1996): Die Vegetation der Châine de Gobnangou. - PhD thesis, Goethe-University Frankfurt.

MüLler J (2004): A Woody Plant Community with Acacia ataxacantha and Anogeissus leiocarpa from Northern Burkina Faso. - Etudes flore veg Burkina Faso 8: 39-44.

MÜLLER J \& WitTIG R (2002): L'état actuel du peuplement ligneux et la perception de sa dynamique par la population dans le Sahel burkinabé - présenté à l'exemple de Tintaboora et de Kollangal Alyaakum / Aktueller Zustand der Gehölzvegetation sowie Wahrnehmung ihrer Dynamik durch die Bevölkerung im burkinischen Sahel - dargestellt am Beispiel von Tintaboora und Kollangal Alyaakum. - Etudes flore veg Burkina Faso 6: 19-30

MÜLleR J \& WitTIG R (2004): The Importance of Acacia L. (Mimosaceae) for the vegetation in the Sahelian Region of Burkina Faso. - Etudes flore veg Burkina Faso 8: 27-38.

MÜLLER JV (2013): Floristic and structural pattern and current distribution of tiger bush vegetation in Burkina Faso (West Africa) assessed by means of belt transects and spatial analysis. Appl Ecol Environment Research 11: 153-171.

Niasse M, Afouda A \& Amani, A (Eds.) (2004): Reducing West Africa's Vulnerability to Climate Impacts on Water Resources, Wetlands and Desertification: Elements for a Regional Strategy for Preparedness and Adaptation. - IUCN, Gland, Switzerland and Cambridge, UK. 66pp.

Rietkerk M, Ketner P, Stroosnijder L \& Prins HHT (1996) Sahelian Rangeland Development; A Catastrophe? J Range Management 49: 512-519.

Sacandé M, Sanou L \& Beentue H (2012):Guide d'identification des arbres du Burkina Faso. - Kew: Royal Botanic Gardens.

Schmidt M (2006): Pflanzenvielfalt in Burkina Faso - Analyse, Modellierung und Dokumentation. - PhD thesis, Goethe University Frankfurt.

Schmidt M, KöNIG K \& MÜLler JV (2008): Modelling species richness and life form composition in Sahelian Bur- 
kina Faso with remote sensing data. J Arid Environment 72: 1506-1517.

Schmidt M, Janssen T, Dressler S, Hahn K, Hien M, Konaté S, Lykke AM, Mahamane A, Sambou B, Sinsin B, Thiombiano A, Wittig R \& Zizka G (2012): The West African Vegetation Database. Biodivers Ecol 4: 105-110.

Thiombiano A, Schmidt M, Dressler S, Ouédraogo A, HAHN K \& ZizKa G (2012): Catalogue des plantes vasculaires du Burkina Faso. Boissiera 65. - Conservatoire et Jardin botaniques, Genève, 391 p.

UNCCD (1994): United Nations Convention to Combat Desertification in those countries experiencing serious drought and/or desertification, particularly in Africa. Document Nr. A/AC.241/27, Paris. URL: http://www.unced.int/Lists/SiteDocumentLibrary/conventionText/conv-eng.pdf.

Wezel A \& LYKKe AM (2006): Woody vegetation change in Sahelian West Africa: evidence from local knowledge. Environment Development Sustainability 8: 553-567.
Wittig R, Hahn-Hadjali K \& Thiombiano A (2003): Les particuliarités de la végétation et de la flore de la Chaîne de Gobnangou dans le Sud-Est du Burkina Faso / Besonderheiten von Flora und Vegetation der Chaîne de Gobnangou und ihres Umlands im Südosten Burkina Fasos. - Étude flore vég Burkina Faso 5: 49-64.

Wittig R, Becker U \& Ataholo M (2011): Weed communities of arable fields in the Sudanian and the Sahelian zone of West Africa. - Phytocoenol 41: 107-141.

ZWARG A (2008): Flora und Vegetation auf Lateritkrusten im Südosten Burkina Fasos. - Diploma thesis, Goethe University Frankfurt, unpublished.

Zwarg A, Schmidt M, Janssen T, Hahn K \& Zizka G (2012): Plant diversity, functional traits and soil conditions of grass savannas on lateritic crusts (bowé) in south eastern Burkina Faso. Flora Veg Sudano-Sambesica 15: 15-24.

E-mail adress: marco.schmidt@senckenberg.de 